УДК $639.211: 597.553 .2(265.53)$

\title{
БИОЛОГИЧЕСКАЯ ХАРАКТЕРИСТИКА, СОСТОЯНИЕ ЗАПАСОВ И ПРОМЫСЕЛ КЕТЫ ONCORHYNCHUS KETA (WALBAUM) В МАГАДАНСКОЙ ОБЛАСТИ В НАЧАЛЕ ХХІ ВЕКА
}

\author{
Волобуев В. В., Горохов М. Н., Коршукова А. М., Голованов И. С. \\ Магаданский филиал ФГБНУ «ВНИРО» («МагаданНИРО»), г. Магадан \\ E-mail: volobuev@magadanniro.ru
}

\begin{abstract}
Приводятся сведения о внутривидовой дифференциации, возрастной, размерно-весовой структуре, абсолютной плодовитости, упитанности, динамике численности подходов, пропуске на нерестилища и вылове кеты за первые два десятилетия XXI в. Анализируются показатели заполнения нерестилищ и их соответствие оптимуму пропуска производителей.
\end{abstract}

Ключевые слова: кета, биологические показатели, поколения, нерестовый подход, вылов, промысел.

DOI: 10.34078/1814-0998-2020-3-66-74

Кета в Магаданской области - один из основных объектов лососевого промысла. В годы неурожайных подходов горбуши кета доминирует по численности в общих подходах тихоокеанских лососей, составляя более $50 \%$. В годы урожайных возвратов горбуши доля кеты снижается до 5-12\%. Кета в Магаданской области представлена двумя экологическими формами - ранней и поздней (Волобуев, 1984, 1990; Волобуев и др., 1990, 1992, 2005), которые можно рассматривать как сезонные расы. Преобладающей формой по численности и распространению является поздняя, ранняя встречается в реках Тауйской губы и в реках юго-западной части зал. Шелихова. В центральной и северо-восточной части зал. Шелихова преобладает поздняя форма кеты. Доля ранней формы в общих подходах вида повысилась с 5-6\% в 1970-1980-е гг. (Евзеров, 1983) до 45-48\% в конце 1990-х гг. (Волобуев, Голованов, 2001). Однако доля ранней формы в подходах может значительно колебаться в зависимости от численности родительских поколений и выживаемости их потомства.

При рассмотрении популяционной структуры кеты в Магаданской области выделены три локальных стада: гижигинское, ямское и тауйское (Волобуев и др., 2004, 2005). Основанием для дифференциации кеты Магаданского региона на отдельные локальные стада послужила выявленная гетерогенность по ряду морфобиологических

\footnotetext{
(C) Волобуев В. В., Горохов М. Н., Коршукова А. М., Голованов И. С., 2020
}

признаков, динамике численности и географическая подразделенность участка нерестового ареала на относительно обособленные группы популяций, интегрируемые в состав указанных стад.

Состояние запасов кеты Магаданского региона описывалось в конце XX - начале XXI столетия (Волобуев, Голованов, 1999, 2001). Конец 1990-х - начало 2000-х гг. характеризуется резким снижением уровня запасов кеты, обусловленным чрезмерным изъятием в прибрежье, мощным незаконным, несообщаемым и нерегулируемым промыслом (ННН-промысел) в нерестовых реках, усугубленным дополнительно морским дрифтерным промыслом в Прикурильских водах и Притауйском (5-м) районе Охотского моря. Целью данной статьи является оценка биологической структуры, состояния ресурсов кеты Магаданской области в начале XXI в. и рассмотрение динамики численности подходов, вылова и пропуска производителей на нерестилища.

\section{МАТЕРИАЛ И МЕТОДЫ}

Материал для публикации собран сотрудниками лаборатории лососевых экосистем МагаданНИРО в 2000-2018 гг. при выполнении полевых работ по изучению биологической структуры популяций кеты в период анадромной миграции, учету численности ее производителей на нерестилищах. Материал для работы в разные годы собран в таких реках, как Гижига, Большая Гарманда, Наяхан, Вилига, Туманы, Яма, Ола, Армань, Яна, Тауй. Объем стандартной разовой пробы кеты на биологический анализ составил 
100 экз. Объем выборок варьировал от 100 до 700 экз. Данные о статистике вылова получены в Охотском территориальном Управлении Росрыболовства. При сборе и обработке материала использовались общепринятые методы исследований (Правдин, 1966; Мордовин, 2009; Волобуев и др., 2012). Всего проанализировано более 32 тыс. рыб, в том числе дифференцированно исследовано 3516 экз. ранней и 4538 экз. поздней форм кеты за 2010-2017 гг. Для расчета пропуска оптимума производителей кеты на нерестилища Магаданской области использованы архивные данные 1970-2000-х гг.

\section{РЕЗУЛЬТАТЫ И ОБСУЖДЕНИЕ}

Внутривидовая дифференциация, биология. Как уже отмечалось, в реках Магаданской области воспроизводятся две экологические формы кеты, различающиеся по морфобиологии, срокам анадромной миграции, местам размножения. Ранняя и поздняя формы кеты различаются по ряду признаков: ранняя кета мигрирует на нерест с начала июня, поздняя - с конца июля; обе формы размножаются на разных типах нерестилищ; нерест ранней заканчивается в августе, поздней - в ноябре; обе формы различаются по биологическим показателям: ранняя форма мельче поздней.

В период размножения ранняя и поздняя формы расходятся в нерестовых водоемах за счет пространственно-темпоральной подразделенности по срокам нереста и привязанности к специфическим биотопам, характеризующимся различной гидрологией: ключевым и подрусловым типами водоснабжения. В связи с особенностями воспроизводства ранняя кета предпочитает для нереста биотопы с подрусловым водоснабжением, ее осенняя раса размножается на выходах грунтовых вод. То есть, упрощенно, раннюю форму кеты можно отнести к русловому экотипу, позднюю - к ключевому. По сути, ранняя форма охотоморской кеты является аналогом амурской летней расы, воспроизводящейся на водах подруслового потока, иногда с примесью более теплых глубинных вод, поздняя - осенней, откладывающей икру на выходах грунтовых вод в ключах и лимнокренах (Кузнецов, 1937; Берг, 1948; Леванидов, 1968; Смирнов, 1975). Кета выделенных форм в Магаданской области может воспроизводиться как симпатрично в бассейне одной реки, так и раздельно в разных реках. Однако на самом деле внутривидовая дифференциация кеты гораздо сложнее, так как описаны различные экотипы кеты, характеризующиеся разной репродуктивной экологией и не подпадающие под классическое определение летней и осенней рас (Волобуев и др., 2016). Так, например, кета Камчатки весеннего и летнего сроков хода на нерест размножается в ключах и лимнокренах на выходах грунтовых вод (Крохин, Крогиус, 1937; Бирман, 1964; Смирнов, 1975), для осенней расы кеты в бассейне Амура и на Сахалине описан экотип, воспроизводящийся на подрусловом потоке (Золотухин, 2009).

Нерестилища кеты ранней формы располагаются в русле рек или в их притоках в местах, не имеющих выходов грунтовых вод, поэтому они в большей степени подвержены обсыханию и промерзанию. Воспроизводство кеты ранней расы осуществляется по горбушовому типу при изменении температуры воды в период инкубации эмбрионов в пределах $13.6-0.1^{\circ} \mathrm{C}$. Поздняя кета размножается на выходах грунтовых вод. Нерест поздней кеты происходит в ключевых протоках и лимнокренах. Установлено, что часть ключевых нерестилищ кеты может не замерзать в течение зимы (Рогатных, Морозов, 1988). Температура грунтовых вод в период инкубации икры поздней кеты колеблется в довольно узком диапазоне. Так, в эксперименте (Волобуев, 1984), в период инкубации икры поздней кеты в ключевой протоке с октября по май температура воды понижалась всего на $3.4^{\circ} \mathrm{C}$, т. е. температурный диапазон инкубации икры у нее более узкий, что, очевидно, повышает выживаемость потомства (Волобуев и др., 2016). При этом следует отметить, что площадь нерестилищ поздней кеты ограничена наличием участков русла с выходами грунтовых вод. Ранее мы отмечали (Волобуев, 1984), что в случае мощных проходов производителей кеты на нерестилища может происходить их переполнение, при этом часть производителей может размножаться на периферии ключевых проток, где выходы грунтовых вод минимальны. В связи с этим можно заметить, что площадь нерестилищ ранней кеты, как и у горбуши, потенциально гораздо больше. При условии достижения ранней кетой оптимальной численности возможен всплеск численности ее подходов, аналогичный тем, что наблюдаются у горбуши.

Очевидно, наличие на охотоморском участке нерестового ареала азиатской кеты разнообразных условий позволяет воспроизводиться как минимум двум экологическим модификациям кеты, реализованным в виде русловой или ключевой форм жизненных стратегий. Они наиболее приспособлены к условиям среды или же, заселив исторически данный район обитания, являются экологически более адаптированными и конкурентоспособными по отношению к другим сезонным формам для того, чтобы оставаться доминирующими. По своим биологическим показателям ранняя охотоморская кета ближе всего к камчатской весенней форме, летней амурской и сахалинской, а поздняя - к камчатской летней форме (Волобуев и др., 2016). 
Таблица 1. Биологическая характеристика ранней формы кеты (на примере популяции р. Тауй) в 2010-2017 гг.

Table 1. Biological characteristics of the early form of the chum salmon (exemplified by the Tauy River population) in 2010-2017

\begin{tabular}{|c|c|c|c|c|c|c|}
\hline \multirow{2}{*}{ Год } & \multirow{2}{*}{$\begin{array}{c}\text { Длина по } \\
\text { Смитту, см }\end{array}$} & \multirow{2}{*}{ Масса тела, кг } & \multirow{2}{*}{$\begin{array}{c}\text { Абс. } \\
\text { плодовитость, } \\
\text { икр. }\end{array}$} & \multicolumn{2}{|c|}{ Упитанность по Фультону } & \multirow[b]{2}{*}{$\mathrm{n}$} \\
\hline & & & & самцы & самки & \\
\hline \multirow{2}{*}{2010} & $\underline{63.6 \pm 0.1}$ & $\underline{3.18 \pm 0.02}$ & $\underline{2524 \pm 26}$ & $\underline{1.52 \pm 0.01}$ & $\underline{1.45 \pm 0.01}$ & \multirow{2}{*}{699} \\
\hline & $53.0-74.0$ & $1.75-5.35$ & $1071-4334$ & $1.15-2.64$ & $0.81-2.57$ & \\
\hline \multirow{2}{*}{2011} & $\underline{64.4 \pm 0.2}$ & $\underline{3.21 \pm 0.03}$ & $\underline{2493 \pm 30}$ & $\underline{1.45 \pm 0.01}$ & $\underline{1.41 \pm 0.01}$ & \multirow{2}{*}{700} \\
\hline & $52.0-77.0$ & $1.60-6.00$ & $952-4307$ & $0.79-1.79$ & $0.81-2.64$ & \\
\hline \multirow{2}{*}{2012} & $\underline{62.4 \pm 0.2}$ & $\underline{3.05 \pm 0.03}$ & $2419 \pm 31$ & $\underline{1.54 \pm 0.01}$ & $\underline{1.49 \pm 0.01}$ & \multirow{2}{*}{550} \\
\hline & $51.0-77.0$ & $1.72-6.21$ & $1148-4038$ & $1.20-2.57$ & $0.83-1.78$ & \\
\hline \multirow{2}{*}{2013} & $62.7 \pm 0.2$ & $\underline{3.10 \pm 0.03}$ & $\underline{2362 \pm 36}$ & $1.60 \pm 0.03$ & $1.47 \pm 0.01$ & \multirow{2}{*}{522} \\
\hline & $\overline{42.5-76.0}$ & $\overline{1.79-5.41}$ & $1007-4240$ & $1.21-2.60$ & $\overline{0.93-2.62}$ & \\
\hline \multirow{2}{*}{2014} & $\underline{63.3 \pm 0,2}$ & $\underline{3.30 \pm 0.04}$ & $\underline{2210 \pm 42}$ & $\underline{1.60 \pm 0.02}$ & $\underline{1.51 \pm 0,02}$ & \multirow{2}{*}{371} \\
\hline & $51.0-75.0$ & $1.66-5.42$ & $968-5120$ & $1.29-2.75$ & $0.76-2.87$ & \\
\hline \multirow{2}{*}{2015} & $62.9 \pm 0.2$ & $2.97 \pm 0.03$ & $2075 \pm 36$ & $1.44 \pm 0.01$ & $1.40 \pm 0.01$ & \multirow{2}{*}{447} \\
\hline & $52.5-73,0$ & $1.72-5.32$ & 1019-3686 & $1.10-2.56$ & $1.12-2,26$ & \\
\hline \multirow{2}{*}{2016} & $\underline{62.4 \pm 0.4}$ & $\underline{3.15 \pm 0.07}$ & $\underline{2673 \pm 101}$ & $\underline{1.57 \pm 0.01}$ & $\underline{1.51 \pm 0.01}$ & \multirow{2}{*}{150} \\
\hline & $52.0-76.0$ & $1.73-5.85$ & $1355-6747$ & $1.32-1.95$ & $1.34-1.82$ & \\
\hline \multirow{2}{*}{2017} & $\underline{60.3 \pm 0.6}$ & $2.62 \pm 0.08$ & $\underline{2350 \pm 45}$ & $1.48 \pm 0.03$ & $1.42 \pm 0.02$ & \multirow{2}{*}{77} \\
\hline & $53.5-66.0$ & $1.89-3.62$ & $1765-2837$ & $1.35-1.59$ & $1.24-1.62$ & \\
\hline \multirow{2}{*}{ 2010-2017 } & $\underline{60.3-64,4}$ & $2.62-3.30$ & 2075-2673 & $\underline{1.44-1.60}$ & $\underline{1.40-1.51}$ & \multirow{2}{*}{3516} \\
\hline & $42.5-77.0$ & $1.60-6.21$ & $952-6747$ & $1.10-2.75$ & $0.76-2.87$ & \\
\hline
\end{tabular}

Примечание. Здесь и далее над чертой - средняя и ошибка средней, под чертой - колебания признака.

Таблица 2. Биологическая характеристика поздней формы кеты (на примере популяции р. Тауй) в 2010-2017 гг.

Table 2. Biological characteristics of the late form of the chum salmon ( exemplified by the Tauy River population ) in 2010-2017

\begin{tabular}{|c|c|c|c|c|c|c|}
\hline \multirow{2}{*}{ Год } & \multirow{2}{*}{$\begin{array}{c}\text { Длина по Смитту, } \\
\text { см }\end{array}$} & \multirow{2}{*}{ Масса тела, кг } & \multirow{2}{*}{$\begin{array}{c}\text { Абс. } \\
\text { плодовитость, } \\
\text { икр. } \\
\end{array}$} & \multicolumn{2}{|c|}{ Упитанность по Фультону } & \multirow{2}{*}{$\mathrm{n}$} \\
\hline & & & & самцы & самки & \\
\hline \multirow{2}{*}{2010} & $\underline{65.6 \pm 0.1}$ & $\underline{3.56 \pm 0.03}$ & $\underline{2320 \pm 32}$ & $1.51 \pm 0.01$ & $\underline{1.49 \pm 0.01}$ & \multirow{2}{*}{600} \\
\hline & $55.0-76.5$ & $1.59-5.64$ & $1040-5310$ & $0.60-2.18$ & $0.93-2.17$ & \\
\hline \multirow{2}{*}{2011} & $\underline{67.2 \pm 0.2}$ & $\underline{4.11 \pm 0.04}$ & $\underline{2645 \pm 35}$ & $\underline{1.64 \pm 0.01}$ & $1.59 \pm 0.01$ & \multirow{2}{*}{499} \\
\hline & $55.0-78.0$ & $1.97-6.65$ & $1441-4111$ & $0.90-2.97$ & $0.92-2.00$ & \\
\hline \multirow{2}{*}{2012} & $63.9 \pm 0.2$ & $\underline{3.35 \pm 0,03}$ & $\underline{2558 \pm 33}$ & $\underline{1.56 \pm 0.01}$ & $1.54 \pm 0.01$ & \multirow{2}{*}{594} \\
\hline & $\overline{51.0-80.0}$ & $1.37-6.50$ & $1120-4648$ & $\overline{0.95-4.92}$ & $0.98-2.65$ & \\
\hline \multirow{2}{*}{2013} & $\underline{64.2 \pm 0.2}$ & $\underline{3.67 \pm 0.03}$ & $\underline{2551 \pm 35}$ & $\underline{1.82 \pm 0.03}$ & $\underline{1.64 \pm 0.01}$ & \multirow{2}{*}{682} \\
\hline & $46.0-77.5$ & $1.60-6.72$ & $925-6075$ & $1.00-4.28$ & $0.94-3.33$ & \\
\hline \multirow{2}{*}{2014} & $64.2 \pm 0,2$ & $\underline{3.40 \pm 0.03}$ & $2588 \pm 61$ & $1.59 \pm 0.01$ & $1.54 \pm 0.01$ & \multirow{2}{*}{504} \\
\hline & $52.0-76.0$ & $1.62-5.77$ & $585-4481$ & $1.17-2.82$ & $0.97-3.32$ & \\
\hline \multirow{2}{*}{2015} & $\underline{63.3 \pm 0.1}$ & $\underline{3.09 \pm 0,01}$ & $\underline{2860 \pm 19}$ & $\underline{1.49 \pm 0.00}$ & $\underline{1.47 \pm 0.00}$ & \multirow{2}{*}{1095} \\
\hline & $53.0-74.0$ & $2.01-5.03$ & $1043-3871$ & $1.11-2,52$ & $1.19-1.79$ & \\
\hline \multirow{2}{*}{2016} & $64.8 \pm 0.3$ & $3.59 \pm 0.05$ & $3561 \pm 119$ & $1.60 \pm 0.02$ & $1.57 \pm 0.02$ & \multirow{2}{*}{197} \\
\hline & $\overline{53.5-74.5}$ & $1.73-5.91$ & 1739-6649 & $1.23-3.13$ & $1.28-2.53$ & \\
\hline \multirow{2}{*}{2017} & $\underline{64.3 \pm 0.2}$ & $\underline{3.47 \pm 0.04}$ & $\underline{2502 \pm 20}$ & $\underline{1,58 \pm 0,02}$ & $\underline{1.54 \pm 0.01}$ & \multirow{2}{*}{367} \\
\hline & $51.0-76.0$ & $1.75-5.59$ & $1216-3039$ & $1.18-4.91$ & $1.17-2.06$ & \\
\hline $2010-$ & $\underline{63.3-67.2}$ & 3.09-3.67 & $2320-3561$ & $\underline{1.49-1.82}$ & $1.47-1.64$ & 4538 \\
\hline 2017 & $46.0-78.0$ & $1.37-6.72$ & $585-6649$ & $0.60-4.92$ & $0.92-3.33$ & 4558 \\
\hline
\end{tabular}

В табл. 1-3 представлены данные, характеризующие основные биологические показатели кеты ранней и поздней форм за ряд лет. Отметим, что ранняя кета мельче поздней в среднем на 3 см и легче на 400-500 г. Кета поздней формы характеризуется большей упитанностью и абсолют- 
ной плодовитостью, что, видимо, обусловлено ее более крупным габитусом. Размах размерновесовых характеристик у рыб обеих форм примерно сходен. Кета ранней и поздней форм достигает длины 78 см и около 7 кг по массе тела. Упитанность самцов выше, чем у самок, а упитанность поздней формы больше, чем ранней. Абсолютная плодовитость кеты поздней формы выше. Состав возрастных групп у ранней и поздней форм кеты также довольно сходен: доминируют рыбы в возрасте 4+ лет - 52.3-54.5\% (см. табл. 3).

Таблица 3. Осредненные показатели (\%) возрастной структуры кеты ранней и поздней форм в 20102017 гг.

Table 3. Averaged indicators (\%) of the chum salmon age structure in the early and late forms in 2010-2017

\begin{tabular}{|l|c|c|c|c|c|}
\hline \multirow{2}{*}{ Эколог. форма } & \multicolumn{5}{|c|}{ Возраст, лет } \\
\cline { 2 - 6 } & $2+$ & $3+$ & $4+$ & $5+$ & $6+$ \\
\hline Ранняя & 2.5 & 34.0 & 52.3 & 10.7 & 0.5 \\
\hline Поздняя & 1.3 & 37.9 & 54.5 & 6.2 & 0.1 \\
\hline
\end{tabular}

Таблица 4. Осредненные показатели возрастной структуры локальных стад кеты Магаданской области в 2001-2017 гг.

Table 4. Averaged indicators of the age structure of the chum salmon local stocks in Magadan Oblast in 2001-2017

\begin{tabular}{|l|c|c|c|c|c|}
\hline \multirow{2}{*}{\multicolumn{1}{|c|}{ Стадо }} & \multicolumn{5}{|c|}{ Возрастная группа } \\
\cline { 2 - 6 } & $2+$ & $3+$ & $4+$ & $5+$ & $6+$ \\
\hline Гижигинское & 1.9 & 43.1 & 48.7 & 6.2 & 0.1 \\
\hline Ямское & 2.3 & 35.4 & 51.2 & 10.9 & 0.2 \\
\hline Тауйское & 1.6 & 33.4 & 54.7 & 10.0 & 0.3 \\
\hline
\end{tabular}

Рассмотрим особенности биологической структуры кеты локальных стад: гижигинского, ямского и тауйского. Нерестовые подходы (возвраты) у кеты формируются в результате одновременного созревания части рыб из разных поколений в возрасте от 1+ (единично) до 6+ лет. Однако наиболее многочисленными в подходах были рыбы возрастных групп $3+$ и 4+ лет, с доминирующей возрастной группой пятилеток $-4+$ лет (табл. 4).

При рассмотрении осредненных биологических показателей кеты трех стад можно заметить, что наиболее крупной является кета ямского стада, очевидно, как результат условий среды обитания, оказывающих влияние на формирующиеся поколения в на- чальный морской период жизни. Как было показано ранее (Волобуев, Волобуев, 2000), выходя в морское прибрежье из Ямского лимана, молодь кеты попадает в зону апвеллинга, создающего район высокой кормности, с биомассой зоопланктона до 1000 мг/м³ (Маркина, Чернявский, 1984), что, по-видимому, обеспечивает ей более благоприятные стартовые условия, чем кете других стад (табл. 5). Размерно-весовые характеристики кеты тауйского и гижигинского стад несколько ниже.

Динамика численности. Вопросам изучения закономерностей динамики численности кеты Магаданской области в разное время уделялось большое внимание (Клоков, 1970, 1973; Волобуев, Волобуев, 2000; Volobuev, 2000; Волобуев, Голованов, 2001; Волобуев и др., 2005). Исследовались динамика запасов (уровень подходов и вылов) в периоды различной численности стад кеты Магаданского региона. В последние годы такого анализа не проводилось. Считаем, что определенный интерес представляет рассмотрение динамики величин подходов, вылова и пропуска на нерест кеты за первые два десятилетия XXI в. Рассмотрим динамику подходов кеты по локальным стадам с 2001 по 2018 г. (рис. 1).

Основные запасы кеты сосредоточены в Гижигинской губе, где воспроизводится гижигинское локальное стадо с подходами свыше 1 млн рыб $(2006,2007,2015,2018$ г.) и максимальными подходами, зарегистрированными в 2007 и 2015 г., - 1.3-1.2 млн рыб. На 2-м месте находятся запасы кеты ямского стада с величинами подходов, приближающимися к 700 тыс. рыб (2001, 2008 г.). Наименьшими запасами характеризуется тауйское стадо кеты. Здесь подходы только в 2010 г. превысили 600 тыс. рыб, во все остальные годы они меньше этой величины.

Таблица 5. Осредненные биологические показатели кеты гижигинского, ямского и тауйского локальных стад в 2001-2017 гг.

Table 5. Averaged biological indicators of chum salmon of the Gizhiga, Yama, and Tauy local stocks in 2001-2017

\begin{tabular}{|c|c|c|c|c|}
\hline \multirow{2}{*}{$\begin{array}{c}\text { Локальное } \\
\text { стадо }\end{array}$} & \multicolumn{4}{|c|}{ Биологический показатель } \\
\hline & $\begin{array}{c}\text { Длина тела } \\
\text { по Смитту, см }\end{array}$ & Масса тела, кг & ИАП, икр. & n, экз. \\
\hline \multirow{2}{*}{ Гижигинское } & $\underline{64.4 \pm 0.1}$ & $\underline{3.34 \pm 0.01}$ & $\underline{2486 \pm 9}$ & \multirow{2}{*}{10078} \\
\hline & $46.0-83.0$ & $1.21-7.56$ & $675-6388$ & \\
\hline \multirow{2}{*}{ Ямское } & $\underline{65.9 \pm 0.1}$ & $\underline{3.46 \pm 0.01}$ & $\underline{2410 \pm 9}$ & \multirow{2}{*}{8590} \\
\hline & $49.0-83.0$ & $1.41-7.39$ & $917-5606$ & \\
\hline \multirow{2}{*}{ Тауйское } & $\underline{64.0 \pm 0.1}$ & $\underline{3.36 \pm 0.01}$ & $\underline{2475 \pm 7}$ & \multirow{2}{*}{13344} \\
\hline & $\overline{49.0-81.0}$ & $1.37-7.71$ & $675-6747$ & \\
\hline
\end{tabular}

Примечание. Над чертой - среднеячеистая ошибка средней, под чертой колебания признака. 


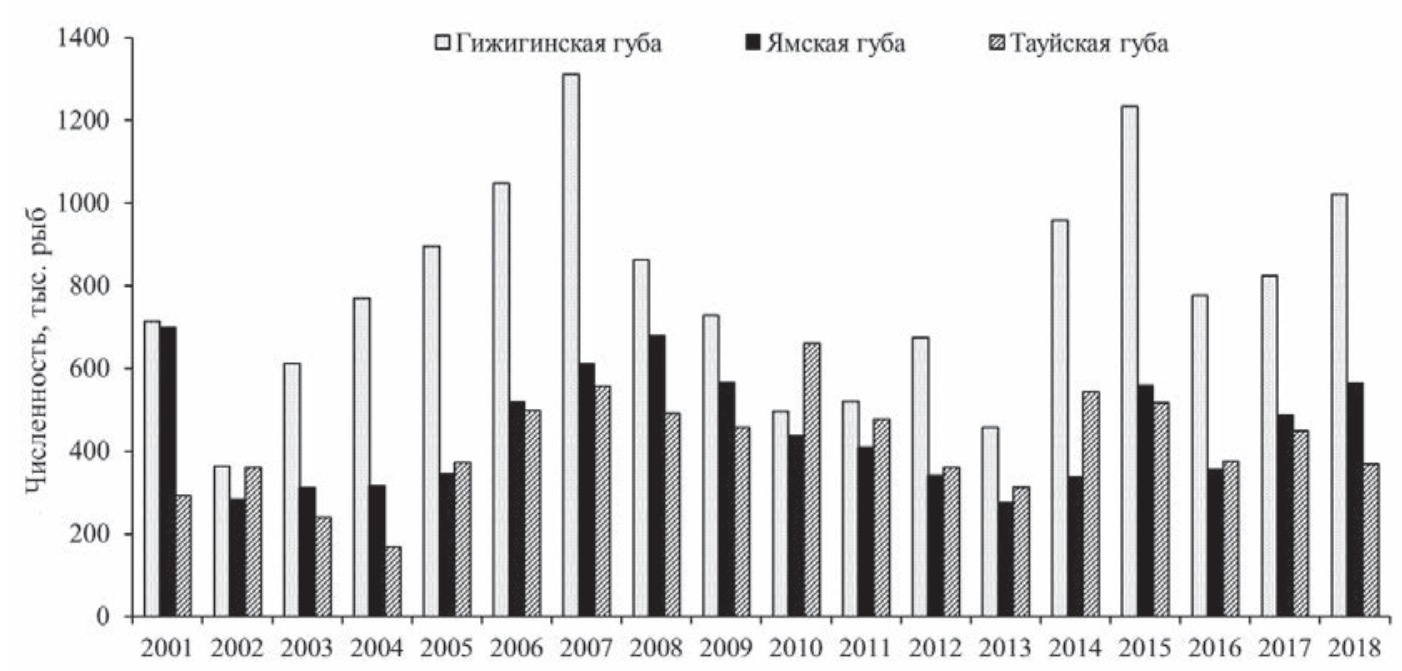

Puc. 1. Подходы кеты по районам промысла и воспроизводства в Магаданской области

Fig. 1. Returns of the chum salmon by areas of fishing and reproduction in Magadan Oblast

При рассмотрении динамики уловов по трем локальным стадам картина диаметрально противоположная подходам: с 2010 г. максимальный вылов кеты отмечен в Тауйской губе и впервые за последние годы в 2018 г. вылов кеты тауйского стада оказался меньше, чем в двух других локальных стадах. То есть высокая промысловая нагрузка ложится на тауйскую кету с 2010 г., а уже к 2018 г. уловы в ней резко падают, что, скорее всего, свидетельствует о перелове. На 2-м месте по вылову стоит кета Гижигинской губы. На этом фоне хорошо заметно, что к 2018 г. возрастает вылов кеты в Ямской губе (рис. 2).

Достаточный уровень пропуска кеты на нерестилища, как правило, является гарантом расширенного воспроизводства, когда численность потомства превышает численность родительского стада. Для оценки оптимума производителей кеты в Магаданской области за основу взят ряд поколений, кратность которых превышала 1. Приняв за основу поколения, которые обеспечивали расширенное воспроизводство и от которых произошли наиболее многочисленные поколения потомков, мы определили среднюю величину производителей, дающую наилучший возврат потомков. Она соответствует 1.27 млн рыб (табл. 6).

То есть, основываясь на этих расчетах, можно полагать, что для обеспечения оптимального уровня заполнения нерестилищ и эффективного воспроизводства кеты в Магаданской области необходимо пропускать на нерестилища около 1.3 млн ее производителей, которые задейству-

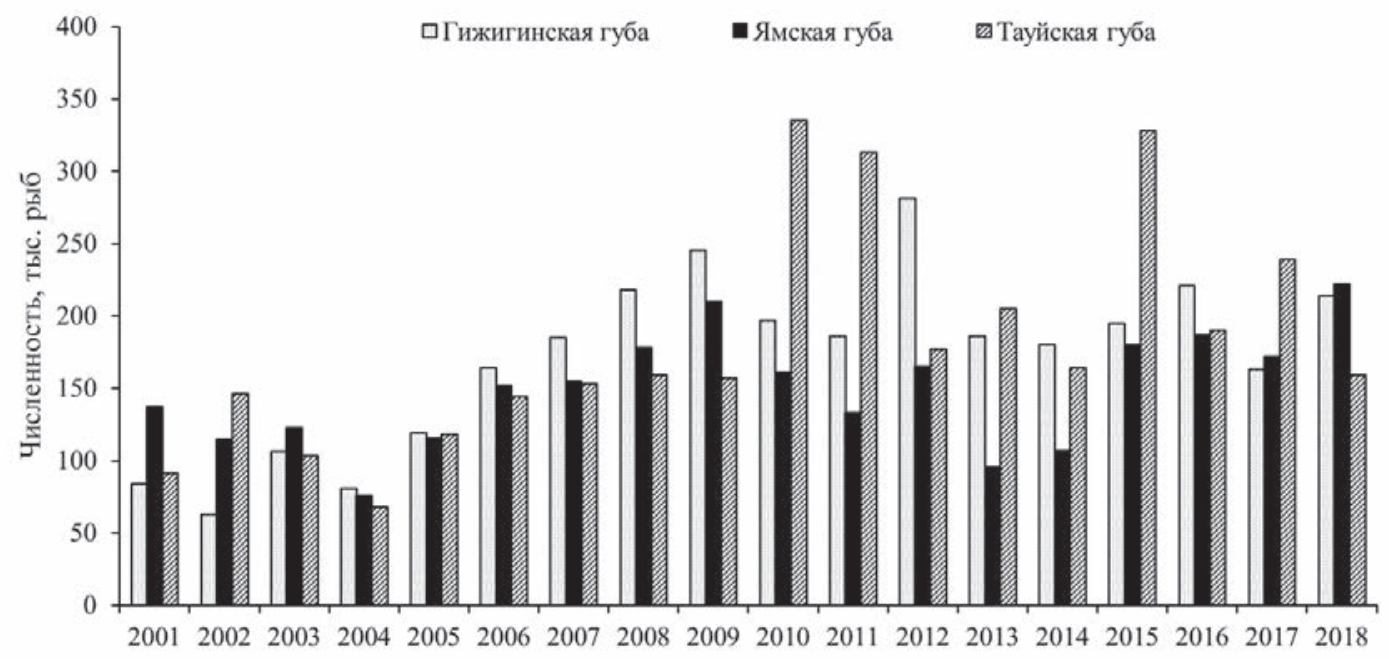

Puc. 2. Вылов кеты по районам промысла и воспроизводства в Магаданской области

Fig. 2. Catch of the chum salmon by areas of fishing and reproduction in Magadan Oblast 
Таблица 6. Расчет оптимума пропуска кеты на нерестилища для Магаданской области, тыс. рыб

Table 6. Calculation of the adult chum salmon optimum on the spawning grounds for Magadan Oblast, ths. specimens

\begin{tabular}{|c|c|c|c|c|}
\hline \multirow{2}{*}{ Поколение } & \multicolumn{2}{|c|}{ Численность, тыс. рыб } & \multirow[t]{2}{*}{$\begin{array}{l}\text { Кратность вос- } \\
\text { производства* }\end{array}$} & \multirow[t]{2}{*}{$\begin{array}{c}\text { Задействован- } \\
\text { ная площадь } \\
\text { нерестилищ, } \text { м² }^{2}\end{array}$} \\
\hline & поколения & потомства & & \\
\hline 1979 & 1216 & 2708 & 2.22 & 1343680 \\
\hline 1982 & 890 & 1630 & 1.83 & 983450 \\
\hline 1984 & 1255 & 2847 & 2.27 & 1386775 \\
\hline 1985 & 905 & 2748 & 3.03 & 1000025 \\
\hline 1986 & 1486 & 2515 & 1.73 & 1642030 \\
\hline 1987 & 1207 & 1607 & 1.33 & 1333735 \\
\hline 1988 & 1367 & 1965 & 1.43 & 1510535 \\
\hline 1990 & 2367 & 3524 & 1.49 & 2615535 \\
\hline 1996 & 1337 & 1538 & 1.15 & 1477385 \\
\hline 2001 & 1393 & 2060 & 1.48 & 1539265 \\
\hline 2003 & 827 & 3142 & 3.80 & 913835 \\
\hline 2004 & 1029 & 1287 & 1.25 & 1137045 \\
\hline 2005 & 1258 & 1658 & 1.32 & 1390090 \\
\hline Средняя & 1272 & 2248 & 1.77 & 1405645 \\
\hline
\end{tabular}

*Для оценки задействованной площади нерестилищ численность производителей поколения умножали на среднюю площадь нерестового бугра кеты, равную $2.21 \mathrm{~m}^{2}$, и делили на 2.

ют под нерест в среднем около 1.4 млн м² нерестовых площадей в реках региона. При разбивке общего оптимума производителей, необходимых для обеспечения расширенного воспроизводства кеты трех локальных стад, получили следующие величины: Гижигинская губа - 660 тыс. рыб, Ямская губа - 340 тыс. рыб и Тауйская губа 272 тыс. рыб.

На рис. 3 показан пропуск производителей по отдельным районам воспроизводства: в Гижигинской, Ямской и Тауйской губах на протя- жении последних 18 лет. Горизонтальными линиями показаны целевые ориентиры управления запасами, являющиеся и оптимальными индикаторами пропуска производителей на нерест для каждого локального стада.

При рассмотрении рис. 3 можно видеть, что уровень требуемого пропуска для рек гижигинского стада не соблюдался с 2008 по 2013 г. С 2014 по 2018 г. оптимум производителей кеты был превышен в трех случаях, а в двух приближался к нему. В реках Ямской губы оптимум пропуска кеты на нерестилища был достигнут всего в шести случаях из 18 наблюденных годоаналогов. Наихудшее положение с обеспеченностью пропуска производителей на нерестилища отмечается в Тауйской губе. Там из 18 лет наблюдений оптимум пропуска был отмечен всего в шести случаях, при этом последние четыре года пропуск производителей на нерестилища был обеспечен не более чем на 60-70\% от уровня оптимума. Это может привести к слабым возвратам этих поколений в 2019-2022 гг.

Таким образом, следует признать, что наименее благополучное состояние естественного воспроизводства кеты наблюдается для тауйского локального стада, воспроизводящегося в реках Тауйской губы. При нынешнем состоянии запасов кеты Тауйской губы сохранение высокой промысловой нагрузки на ее популяции может привести к депрессии. В связи с этим считаем необ-

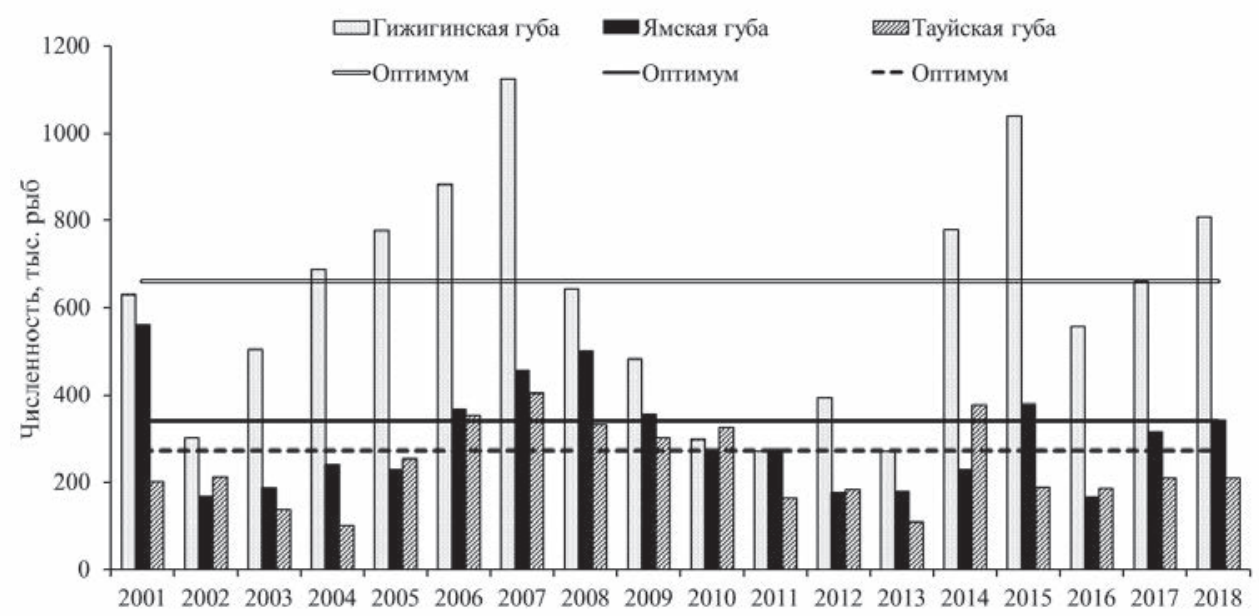

Puc. 3. Пропуск производителей кеты на нерестилища в Магаданской области

Fig. 3. Escapement of chum salmon to the spawning grounds in Magadan Oblast 
ходимым ограничивать интенсивность промысла кеты в Тауйской губе за счет перераспределения промысловой нагрузки на популяции кеты Гижигинской губы. Кроме того, в ходе предстоящих лососевых путин в обязательном порядке следует вводить проходные дни с целью обеспечить пропуск производителей кеты на нерестилища и ограничивать промысловые мощности ставных морских и закидных речных неводов в Тауйской губе.

\section{ЗАКЛЮЧЕНИЕ}

Внутривидовая неоднородность североохотоморской кеты и условия среды, по-видимому, способствовали образованию двух вариантов жизненных стратегий - летней ранней и летней поздней экологических форм (рас), аналогичных летней и осенней расам амурской кеты. Существование двух экологических форм кеты нашло отражение и в особенностях их биологической структуры: ранняя форма отличается меньшими размерно-весовыми показателями, плодовитостью и упитанностью. Формирование жизненных стратегий и особенностей репродуктивной экологии, очевидно, расширяет границы обитания и выживания, а экологический полиморфизм кеты способствует более широкому освоению ареала, внутривидовому многообразию и устойчивости существования вида в пространстве и времени. Внутривидовая дифференциация кеты зависит от разнообразия факторов среды обитания, и, как вид экологически пластичный, она способна образовывать ряды жизненных форм с той или иной репродуктивной стратегией, которые с успехом можно использовать в практической деятельности, например, в рыбоводстве, аквакультуре, организации рекреационного рыболовства. В Магаданской области кета характеризуется двумя четко дифференцированными формами, в других регионах, например, на Камчатке или в бассейне Амура, ее внутривидовое разнообразие гораздо шире.

Анализ количественных характеристик и динамики численности подходов, вылова и пропуска производителей на нерестилища по трем локальным стадам магаданской кеты позволил сделать вывод о дисбалансе промысловой нагрузки на запасы двух локальных стад - гижигинского и тауйского. Устоявшаяся практика промысла показывает чрезмерный пресс промысловой нагрузки на кету Тауйской губы и дефицит производителей на нерестилищах при недоосвоении ресурсов Гижигинской губы. В связи с этим считаем целесообразным перенести часть промысловой нагрузки на популяции кеты Гижигинской губы, а за основу промысловой стратегии в Тауйской губе необходимо принять обязательный пропуск достаточного количества производите- лей кеты на нерест, обеспечивающий расширенный уровень ее воспроизводства. Для этого необходимо использовать ограничение интенсивности промысла ставными морскими и речными закидными неводами, а также в обязательном порядке вводить проходные дни, обеспечивающие беспрепятственный пропуск кеты на нерест в реки Тауйской губы.

\section{ЛИТЕРАТУРА}

Берг Л. С. Рыбы пресных вод СССР и сопредельных стран. Москва ; Ленинград : Изд-во АН СССР, 1948. Ч.1. $466 \mathrm{c.}$

Бирман И. Б. Некоторые данные к исследованию локальных стад и расового состава камчатской кеты // Вопросы географии Камчатки. 1964. Вып. 2. С. 82-87.

Волобуев В. В. Об особенностях размножения кеты Oncorhynchus keta (Walbaum) (Salmonidae) и экологии ее молоди в бассейне р. Тауй // Вопросы ихтиологии. 1984. Т. 24. Вып. 6. С. 953-963.

Волобуев В. В. Внутривидовая структура и пути формирования популяций кеты Oncorhynchus keta (Walbaum) материкового побережья Охотского моря : тез. докл. междунар. симп. по тихоокеанским лососям. Владивосток, 1990. С. 15-17.

Волобуев В. В., Волобуев М. В. Экология и структура популяций как основные элементы формирования жизненной стратегии кеты Oncorhynchus keta континентального побережья Охотского моря // Вопросы ихтиологии. 2000. Т. 40, № 4. С. 510-529.

Волобуев В. В., Голованов И. С. Запасы лососей североохотоморского побережья // Рыбное хозяйство. 1999. № 2. C. 36-37.

Волобуев В. В., Голованов И. С. Запасы тихоокеанских лососей Магаданской области : сб. науч. тр. МагаданНИРО. Магадан, 2001. Вып. 1. С.123-133.

Волобуев В.В., Бачевская Л. Т., Волобуев М. В., Марченко C. Л. Популяционная структура кеты Oncorhynchus keta (Walbaum) континентального побережья Охотского моря // Вопросы ихтиологии. 2005. Т. 45, № 4. C. 489-501.

Волобуев В. В., Марченко С. Л., Волобуев М. В. Популяционная структура и динамика численности кеты Oncorhynchus keta (Walbaum) материкового побережья Охотского моря : сб. науч. тр. МагаданНИРО. 2004. Вып. 2. С. 237-258.

Волобуев В. В., Мордовин А. И., Голованов И. С. О методах количественного учета тихоокеанских лососей, применяемых в Магаданской области : тез. докл. юбилейной конф. 80-летия КамчатНИРО. 2012. C. 296-301.

Волобуев В. В., Овчинников В. В., Волобуев М. В. Особенности воспроизводства тихоокеанских лососей рода Oncorhynchus материкового побережья Охотского моря // Вопросы рыболовства. 2016. Т. 17, № 2. C. 1-21.

Волобуев В. В., Рогатных А. Ю., Кузищчин К. В. О внутривидовых формах кеты Oncorhynchus keta материкового побережья Охотского моря // Вопросы ихтиологии. 1990. Т. 30. Вып. 2. С. 221-228. 
Волобуев В. В., Рогатных А. Ю., Кузищчин К. В. Царев Ю. И. Морфологическая дифференциация ранней и поздней кеты Oncorhynchus keta (Walb.) р. Тауй // Популяционная биология лососей Северо-Востока Азии. Владивосток, 1992. С. 72-80.

Евзеров A. B. Нерестовый фонд охотоморской и анадырской кеты // Биол. основы развития лососевого хозва в водоемах СССР. Москва : Наука, 1983. С. 103-113.

Золотухин В. Ф. Экологические формы кеты бассейна реки Амур // Бюл. № 4. Реализации «Концепции дальневост. бас. Программы изучения тихоокеанских лососей». 2009. С. 148-149.

Клоков В. К. К вопросу о динамике численности нерестовых стад лососей на Северном побережье Охотского моря // Известия ТИНРО. 1970. Т. 71. C. $169-177$.

Клоков В. К. Динамика численности кеты в различных районах Северного побережья Охотского моря // Там же. 1973. Т. 86. С. 66-80.

Крохин Е. М., Крогиус Ф. В. Очерк бассейна p. Большой и нерестилищ лососевых, расположенных в нем // Там же. 1937. Т. 9. С. 1-157.

Кузнецов И. И. Кета и ее воспроизводство. Хабаровск : Дальгиз, 1937. 175 с.
Леванидов В. Я. О гидрологическом режиме нерестилищ кеты и горбуши // Известия ТИНРО. 1968. Т. 64. C. 101-125.

Маркина Н. П., Чернявский В. И. Количественное распределение планктона и бентоса в Охотском моpe // Там же. 1984. Т. 109. С. 109-119.

Мордовин А. И. О методах учета водных биологических объектов: история вопроса, применяемые и перспективные методы : сб. науч. тр. МагаданНИРО. Магадан, 2009. Вып. 3. С.182-191.

Правдин И. Ф. Руководство по изучению рыб. Москва : Пищ. пром-сть, 1966. 376 с.

Рогатных А. Ю., Морозов Л. И. Оценка условий воспроизводства кеты Oncorhynchus keta и кижуча Oncorhynchus kisutch по величине незамерзающих участков рек // Вопросы ихтиологии. 1988. Т. 28. Вып. 4. C. 692-694.

Смирнов А. И. Биология, размножение и развитие тихоокеанских лососей. Москва : Изд-во МГУ, 1975. $334 \mathrm{c}$.

Volobuev $V$. $V$. Long-term changes in the biological parameters of chum salmon of the Okhotsk Sea // Bull. NPAFC. 2000. No. 2. P. 175-180.

Поступила в редакиию 21.03.2019 2.

Поступила после доработки 12.10.2019 2.

\title{
BIOLOGICAL CHARACTERISTICS, STATUS OF RESOURCES, AND FISHING FOR THE ONCORHYNCHUS KETA (WALBAUM) IN MAGADAN OBLAST IN THE EARLY $21^{\text {ST }}$ CENTURY
}

\author{
V. V. Volobuev, M. N. Gorokhov, A. M. Korshukova, I. S. Golovanov
}

\section{Magadan Branch of Russian Federal Research Institute of Fisheries and Oceanography "VNIRO", Magadan}

Information on intraspecific differentiation, age, size and weight structure, absolute fecundity, fatness, dynamics of the number of returns, escapement to spawning grounds, and catch of the chum salmon in the first two decades of the $21^{\text {st }}$ century is presented. The indicators of chum salmon to spawning grounds filling and their compliance to the optimum number of spawning chum salmon are analyzed.

Keywords: chum salmon, biological indicators, generations, spawning returns, catch, fishing.

\section{REFERENCES}

Berg, L. S., 1948. Freshwater Fishes of the USSR and Adjacent Countries. Moscow, Leningrad, USSR Academy of Sciences, Part 1 [In Russian].

Birman, I. B., 1964. Some Data to the Study of Local Stocks and Race Composition of the Kamchatka Chum Salmon, Geography Issues of Kamchatka. 2, 82-87 [In Russian].

Klokov, V. K., 1970. On the Issue of the Dynamics of the Pacific Salmon Spawning Stocks at the Northern Coast of the Sea of Okhotsk, Izvestiya TINRO. 71, 169177 [In Russian].
Klokov, V. K., 1973. The Dynamics of the Chum Salmon Abundance in Different Parts of the Northern Coast of the Sea of Okhotsk, Izvestiya TINRO. 86, 6680 [In Russian].

Krokhin, E. M., Krogius, F. V., 1937. Sketch of the Bol'shaya River Basin and Pacific Salmon Spawning Grounds Located in It, Ibid. 9, 157 [In Russian].

Kuznetsov, I. I., 1937. Chum Salmon and Its Reproduction. Khabarovsk, Dal'giz [In Russian].

Levanidov, V. Ya., 1968. On the Hydrological Regime of Chum and Pink Salmon Spawning Grounds, Izvestiya TINRO. 64, 101-125 [In Russian]. 
Markina, N. P., Chernyavsky, V. I., 1984. Quantitative Distribution of Plankton and Benthos in the Sea of Okhotsk, Ibid. 109, 109-119 [In Russian].

Mordovin, A. I., 2009. On Methods of Accounting for Aquatic Biological Objects: Background, Applied and Perspective Methods, Sbornik Nauchnych Trudov MagadanNIRO. Magadan, 3, 182-191 [In Russian].

Pravdin, I. F., 1966. Fish Study Manual. Moscow, Pischevaya Promyshlennost' [In Russian].

Rogatnykh, A. Yu., Morozov, L. I., 1988. Assessment of Reproduction Conditions of Chum Salmon Oncorhynchus keta and Coho Salmon Oncorhynchus kisutch by the Size of Non-Freezing Sections of Rivers, Voprosy Ikhtiologii. 28 (4), 692-694 [In Russian].

Smirnov, A. I., 1975. Biology, Reproduction, and Development of Pacific Salmon, Moscow, Lomonosov Moscow State University [In Russian].

Volobuev, V. V., 1984. On the Features of Chum Salmon Oncorhynchus keta (Walbaum) (Salmonidae) Reproduction and the Ecology of Its Juveniles in the Tauy River, Voprosy Ikhtiologii. 24, 6, 953-963 [In Russian].

Volobuev, V. V., 1990. Intraspecific Structure and Paths for the Formation of Chum Salmon Oncorhynchus keta (Walbaum) Populations at the Continental Coast of the Sea of Okhotsk, Abstracts of the International Simposium on the Pacific Salmon. Vladivostok, 5-17 [In Russian].

Volobuev, V. V., 2000. Long-Term Changes in the Biological Parameters of Chum Salmon of the Okhotsk Sea, North Pacific Anadromous Fish Commission Bulletin. 2, 175-180.

Volobuev, V. V., Bachevskaya, L. T., Volobuev, M. V., Marchenko, S. L., 2005. Population Structure of Chum Salmon Oncorhynchus keta (Walbaum) at the Continental Coast of the Sea of Okhotsk, Voprosy Ikhtiologii. 45, 4, 489-501 [In Russian].

Volobuev, V. V., Golovanov, I. S., 1999. Salmon Stocks of the Northern Okhotsk Coast, Fisheries. 2, 36-37 [In Russian].

Volobuev, V. V., Golovanov, I. S., 2001. Stocks of Pacific Salmon in Magadan Oblast, Sbornik Nauchnych
Trudov MagadanNIRO. Magadan. Iss. 1, 123-133 [In Russian].

Volobuev, V. V., Marchenko, S. L., Volobuev, M. V., 2004. Population Structure and Dynamics of the Numbers of Chum Salmon Oncorhynchus keta (Walbaum) at the Continental Coast of the Sea of Okhotsk, Ibid. Magadan, 2, 237-258 [In Russian].

Volobuev, V. V., Mordovin, A. I., Golovanov I. S., 2012. On the Methods of Quantitative Accounting of Pacific Salmon Used in Magadan Oblast, Abstracts of the Conference Dedicated to the $80^{\text {th }}$ Anniversary of KamchatNIRO. 296-301 [In Russian].

Volobuev, V. V., Ovchinnikov, V. V., Volobuev, M. V., 2016. Reproduction Features of the Pacific Salmon of the Genus Oncorhynchus at the Continental Coast of the Sea of Okhotsk, Problems of Fisheries. 17, 2, 1-21 [In Russian].

Volobuev, V. V., Rogatnykh, A. Yu., Kuzishchin, K. V., 1990. On the Intraspecific Forms of Chum Salmon Oncorhynchus keta at the Continental Coast of the Sea of Okhotsk, Ibid. 30, 2, 221-228 [In Russian].

Volobuev, V. V., Rogatnykh, A. Yu., Kuzishchin, K. V., Tsaryov, Yu. I., 1992. Morphological Differentiation of the Early and Late Chum Salmon Oncorhynchus keta (Walb.) of the Tauy River, Population Biology of Salmon in North-East Asia. Vladivostok, 72-80 [In Russian].

Volobuev, V. V., Volobuev, M. V., 2000. Ecology and Structure of Populations as the Main Elements of the Formation of Chum Salmon Oncorhynchus keta Life Strategy at the Continental Coast of the Sea of Okhotsk, Voprosy Ikhtiologii. 40, 4, 510-529 [In Russian].

Yevzerov, A. V., 1983. The Spawning Fund of the Okhotsk Sea and the Anadyr River Chum Salmon, Biological Bases for the Development of Salmon Households in the USSR Water Bodies. Moscow, Nauka, 103-113 [In Russian].

Zolotukhin, V. F., 2009. Ecological Forms of the Chum Salmon in the Amur River Basin, Realization of the "Concept of the Far Eastern Basin of the Program of the Pacific Salmon Studies". 4, 148-149 [In Russian]. 